IZA DP No. 5417

Wage Inequality and Returns to Education in Turkey:

A Quantile Regression Analysis

Aysit Tansel

Fatma Bircan

December 2010 


\title{
Wage Inequality and Returns to Education in Turkey: A Quantile Regression Analysis
}

\author{
Aysit Tansel \\ Middle East Technical University \\ ERF and IZA \\ Fatma Bircan \\ Karaelmas University

\section{Discussion Paper No. 5417 \\ December 2010} \\ IZA \\ P.O. Box 7240 \\ 53072 Bonn \\ Germany \\ Phone: +49-228-3894-0 \\ Fax: +49-228-3894-180 \\ E-mail: iza@iza.org
}

Any opinions expressed here are those of the author(s) and not those of IZA. Research published in this series may include views on policy, but the institute itself takes no institutional policy positions.

The Institute for the Study of Labor (IZA) in Bonn is a local and virtual international research center and a place of communication between science, politics and business. IZA is an independent nonprofit organization supported by Deutsche Post Foundation. The center is associated with the University of Bonn and offers a stimulating research environment through its international network, workshops and conferences, data service, project support, research visits and doctoral program. IZA engages in (i) original and internationally competitive research in all fields of labor economics, (ii) development of policy concepts, and (iii) dissemination of research results and concepts to the interested public.

IZA Discussion Papers often represent preliminary work and are circulated to encourage discussion. Citation of such a paper should account for its provisional character. A revised version may be available directly from the author. 
IZA Discussion Paper No. 5417

December 2010

\section{ABSTRACT \\ Wage Inequality and Returns to Education in Turkey: A Quantile Regression Analysis ${ }^{*}$}

This paper investigates the male wage inequality and its evolution over the 1994-2002 period in Turkey by estimating Mincerian wage equations using OLS and quantile regression techniques. Male wage inequality is high in Turkey. While it declined at the lower end of the wage distribution it increased at the top end of wage distribution. Education contributed to higher wage inequality through both within and between dimensions. The within-groups inequality increased and between-groups inequality decreased over the study period. The latter factor may have dominated the former contributing to the observed decline in the male wage inequality over the 1994-2002. Further results are provided for the wage effects of experience, public sector employment, geographic location, firm size, industry of employment and their contribution to wage inequality. Recent increases in FDI inflows, openness to trade and global technological developments are discussed as contributing factors to the recent rising within-groups wage inequality.

JEL Classification: J31, J23, J24, I21

Keywords: $\quad$ wage inequality, returns to education, quantile regression, Turkey

Corresponding author:

Aysit Tansel

Department of Economics

Middle East Technical University

06531 Ankara

Turkey

E-mail: atansel@metu.edu.tr

\footnotetext{
* This article is based on a chapter of Fatma Bircan's Ph.D. thesis (Bircan, 2005) prepared under the supervision of Aysit Tansel at the Department of Economics, Middle East Technical University. Fatma Bircan would like to thank Hakan Ercan, Burak Günalp, Yusuf Ziya Özcan, and Fikret Şenses for their helpful comments on her Ph.D. thesis. We would like to thank Ömer Demir, the former president of Turkish Statistical Institute and Murat Karakaş, chief of Income and Expenditure Statistics, and his staff Özlem Sarıca and Sema Alıcı for their kind help in obtaining and processing the data. This paper is presented at the ESPE conference, 22-24 June, 2006 in Verona, Italy. We would like to thank participants of this conference, Tuncer Bulutay, Murat G. Kırdar and Semih Tümen for their helpful comments.
} 


\section{Introduction}

Wages constitute the largest component of individual income. An understanding of the evolution of wages and the level of wage inequality is essential for an understanding of the labor market dynamics in relation to internal migration, poverty or monetary incentives facing the workers and the young. Wage inequality reflects the structure of wages and the welfare differences among people. The evolution of the wage structure gives an idea about how welfare distribution moves over time. An increase in wage inequality implies polarization in the welfare distribution in the society.

Evolution of wages, wage inequality, and their relation to education using quantile regression model have been studied extensively in the developed countries. Examples include Buchinsky (1994) for the United States, Abadie (1997) and Budria and Moro-Egide (2008) for Spain, Hartog et al. (2001) and Machado and Mata (2001; 2005), Martins (2004) and Andini (2007) for Portugal, Ferstere and Winter-Ebmer (1999) for Australia, Gosling et al. (2000) for the UK, Prasad (2000) and Gernandt and Pfeiffer (2006) for Germany, MacGuinness et al. (2009) for Ireland, Pereira and Martins (2002), Martins and Pereira (2004), Budria and Pereira (2005) and PrietoRodriguez et al. (2008) for several European countries. Lemieux (2007) provides a review of the discussions on secular growth in wage inequality in the United States and other advanced industrialized countries. This topic is studied less often in the developing countries. Recent examples include Blom et al. (2001) and Gonzales and Miles (2001) who studied the wage inequality in Brazil and Uruguay respectively. Patrinos et al. (2009) studied the wage inequality in several Latin American and East Asian countries. Other studies from developing countries, which study the returns to 
education by quantile regression include Mwabu and Schultz (1996) in South Africa, Girma and Kedir (2003) in Ethiopia and Falaris (2008) in Panama.

This paper studies the male wage inequality and its evolution from 1994 to 2002 in Turkey ${ }^{1}$. This is the first analysis of male wage inequality in Turkey. We estimate Mincerian wage equations for male wage earners by OLS and quantile regression techniques using 1994 and 2002 survey results. Special attention is paid to the connection between education and wage inequality. Main findings include the following. Male wage inequality in Turkey is high. Although the overall male wage inequality exhibited a small decline over the period of 1994-2002, a closer examination indicates that wage inequality declined at the lower end of the wage distribution and increased at the top end of wage distribution. Education had a positive impact on within-groups and between-groups inequality with the largest contribution by university education in both 1994 and 2002. Within-groups wage inequality increased however, the between-groups inequality decreased over the study period. The latter effect may have dominated the former contributing to the observed decline in male wage inequality over the period 1994-2002. Further, most of the other covariates had negative impacts on within-groups inequality and they contributed to the overall decline in male wage inequality observed during this period. Finally, increased foreign direct investment inflows, openness to trade and global technological developments favoring skilled labor which are observed recently are discussed as the possible causes of the rising within-groups wage inequality.

This paper is organized as follows. Section 2 describes the Turkish education system and educational attainment of the population. Recent developments in the Turkish economy and the labor market are also provided in this section. Section 3 
presents the quantile regression model. Information about the data sets and the variables used in the analysis are given in Section 4 together with wage and educational distributions. Section 5 presents the ordinary least squares and the quantile regression estimates of the wage equations together with the estimates for returns to education. Section 6 digresses on the possible causes of rising within-groups wage inequality. Conclusions appear in Section 7.

\section{Education System and the Recent Economic Developments}

\section{1. Education System in Turkey}

Until 1997, the educational system in Turkey consisted of five years of primary school, three years of middle school, three years of high school, three or four years of vocational high school and university education which provide two to six years of training depending on the program of study. In 1997 a major educational reform extended the compulsory education from five years to eight years covering the middle school. In 1992, twenty-five new universities were established expanding university education opportunities greatly. These two developments significantly increased the educational attainment of the population recently. Gender gap in education improved substantially over time. Enrollments increased at all levels. Adult literacy increased from 90 percent for men and 67 percent for women in 1990 to 95 percent for men and 80 percent for women in 2002. The average number of years of schooling achieved was 5.37 years in 1990. It reached to 7.01 years for boys and 4.96 years for girls in 2000. Secondary education enrollment rates increased from 46 percent for boys and 30 percent for girls in 1990 to 81 percent for boys and 60 percent for girls in 2002 (Turkish Statistical Institute, 2006).Thus, we can talk about an increase in the supply of educated labor in particular at the middle school level and the university level. 


\section{2. Recent Economic Developments in Turkey}

Turkish economy experienced several major shocks since the early 1990s. First crisis of the period was in 1991 during which Turkish economy was adversely affected by the Gulf War. Second crisis occurred in 1994 when GDP dropped by 6.1 percent and the Turkish Lira was devalued by 70 percent against the US dollar. A stabilization program was adopted in April 1994. Third significant drop in per capita GDP occurred in 1999. This year, the two major earthquakes and the Russian crisis adversely affected the Turkish economy. The earthquakes occurred in the industrial heartland of the country, killing thousands and destroying establishments. Finally, the severest crisis of Turkey's recent history occurred in November 2000 and February 2001. The per capita GDP declined by 9.6 percent in 2001 but recovered quickly in 2002 with a growth rate of 8 percent and achieved high growth rates since then. However, the adverse labor market impact of the 2001 crisis was large and the subsequent output growth has not led to improvements in the unemployment rates. This is dubbed as the "jobless growth”. Employment declined and remained below the pre-crisis level until 2004. In 2004, unemployment rate in urban areas reached 16 percent and that of the educated youth was 30 percent. Thus, we can talk about a decrease in demand for labor during this period.

\section{The Model}

An ordinary least squares (OLS) model is based on the mean of the conditional distribution of the dependent variable. However, it may be of interest to know the effects of the exogenous variables at different points of the conditional distribution of the dependent variable. This is accomplished with the quantile regression model 
which was first introduced by Koenker and Basset (1978). In a wage equation context, the quantile regression model can be written as:

$$
\ln \mathrm{W}_{\mathrm{i}}=\mathrm{X}_{\mathrm{i}} \beta_{\theta}+\mathrm{e}_{\theta \mathrm{i}} \quad \text { with } \text { Quant }_{\theta}\left(\ln \mathrm{W}_{\mathrm{i}} \mid \mathrm{X}_{\mathrm{i}}\right)=\mathrm{X}_{\mathrm{i}} \beta_{\theta}
$$

where $\beta_{\theta}$ is the vector of parameters and $X_{i}$ is the vector of exogenous variables. Quant $_{\theta}(\ln W \mid X)$ denotes the $\theta^{\text {th }}$ conditional quantile of $\ln W$ given $X$. The $\theta^{\text {th }}$ regression quantile, $0<\theta<1$, is defined as a solution to minimizing $\sum \rho_{\theta}(\ln W, X \mid \beta)$ over $\beta$ where $\rho_{\theta}$ is the check point function defined as $\rho_{\theta}(\mathrm{z})=\theta \mathrm{z}$ if $\mathrm{z} \geq 0$ or $\rho_{\theta}(\mathrm{z})=$ $(\theta-1) \mathrm{z}$ if $\mathrm{z}<0$. Thus, the quantile regression minimizes not the sum of squared residuals as in OLS but an asymmetrically weighted sum of absolute errors (Koenker and Hallock, 2001). Linear programming methods are used to solve this minimization problem and the standard errors of the coefficient estimates are obtained by using bootstrap methods proposed by Buchinsky (1998b). In the OLS estimation, the wage effect of a change in one of the exogenous variables say education is to shift the conditional log-wage distribution. However, in the case of the quantile regression not only the location but also the shape of the log-wage distribution changes. Further, quantile regression provides estimates robust to the outliers of the dependent variable, wages and they are also more efficient than the OLS under non-normality of the error terms.

The empirical specification of the model is as follows. $\ln \mathrm{W}$ is the natural logarithm of the real hourly wage. The set of exogenous variables in $\mathrm{X}$ includes individual characteristics such as education, experience, geographic location, firm attributes such as firm size, public ownership status and various industry indicators (Mincer, 1974). We estimated two versions of this model. In one version we used the total years of schooling of the individual ${ }^{2}$. In the second version, we used a set of dummy variables indicating the level of schooling completed. The categories 
considered are illiterate, literate but not graduate of any school (nongraduate for short) and graduates of primary school, middle school, high school, vocational high school, and finally university and post graduate studies. The reference category is the illiterate. There is a linear and a quadratic term in potential experience which is defined as age minus years of schooling minus six (Mincer, 1974). Three cohort dummies are defined for individuals in the 15-24, 25-45 and 45-65 age cohorts. The 15-24 age cohort is the reference category. The geographic location is represented by urban and rural dummy variables. Urban areas are those with population over 20,000. Rural is the reference category. Two dummy variables represent the sector of work such as public versus private. Private is the reference category. Public sector takes a value of one for those workers who are employed in the State Owned Enterprises and Public Administration. Firm size is represented by three dummy variables such as, firms with less than 10, 10-25 and more than 25 employees. Firms with less than 10 employees is the reference category. Finally, 14 different industry indicators are identified and included in the empirical specification with agriculture as the reference category.

\section{The Data and the Distributions of Wages and Education}

\subsection{The Data}

This study is based on the data from 1994 Household Income and Consumption Expenditure Survey and 2002 Household Budget Survey conducted by the Turkish Statistical Institute. Both of the surveys covered all geographical regions throughout the country. A total of 26,256 and 9,600 households were interviewed in 1994 and 2002 respectively over 12 months in urban and rural areas. In this study we consider only the male wage earners, 15-65 years of age. The wage earners who did not work in the survey month and/or did not report positive income for that month are 
deleted. The apprentices who worked for pay during the survey month are included in 2002 but not in 1994 since such information is not available in 1994. The second job holders are included in 2002 but not in 1994 since their hours of work on the second job is not recorded in 1994. The latter two groups are only a very small proportion of total sample. The wage earnings include monthly cash and in-kind payments from the main job in 1994 and additionally from the second job in 2002 for those who held a second job. The monthly income is deflated by using the monthly consumer price index (CPI) with base 1987. The monthly CPI is available for 19 cities and seven geographic, rural and urban regions. The real monthly income is first divided by 4.3 to obtain weekly real wages which in turn is divided by weekly hours of work to reach real hourly wages.

\subsection{Changes in Wage and Education Distributions}

Table 1 gives the evolutions of simple measures of wage inequality computed for 1994 and 2002. Following patterns emerge. First, the mean real hourly wage (rhw) declined between 1994 and 2002 by 2.4 percent. Second, while wages of the least skilled as measured by the lower quantiles of the wage distribution increased, the wages of the most skilled as measured by the median and the upper quantiles of the wage distribution decreased. The ratios between wages at different quantiles are simple measures of overall wage inequality. The ratio of wages indicate there was an increase in wage inequality at the top of the distribution and a decrease in wage inequality at the bottom of the distribution. Examination of the log wage dispersion leads to the similar conclusions about wage inequality over 1994-2002. The (ln q90-ln q10) gap has declined indicating a decrease in wage inequality. However, wage inequality declined at the low end of the wage distribution but increased at the top end of the wage distribution. The log wage dispersion between the highest and lowest 
quantiles are 2.12 in 1994 and 2.03 in 2002 which indicate rather high male wage inequality. The same measure is 1.46 for the United States in 1988 (Juhn et al., 1993) and 1.49 for Portugal in 1994 (Machado and Mata, 2001). In Turkey, the income inequality is one of the highest in the world which exhibited slight declining trend recently. The Gini coefficient which was 0.49 in 1994 declined to 0.44 in 2002 and 0.43 in 2003 (Turkish Statistical Institute, 2006). The high level of income inequality is also indicated by the distribution of the income received by the quintiles. In 1994 (2002) the share of the first quintile in income was 4.9 (5.3) and that of the last quintile was 54.9 (50.0) percent (Turkish Statistical Institute, 2007). These numbers imply that people in the last quintile received a share 11 (9.4) times larger than the share of the people in the first quintile in 1994 (2002) decreasing but high level of income inequality.

The educational distribution of the male wage earners as shown at the bottom part of Table 1 changed considerably from 1994 to 2002. The male mean years of schooling increased from about seven years in 1994 to about eight years in 2002 reflecting the increased years of compulsory schooling from five to eight years in 1997. There is a marked increase in the percentage of male wage earners at the middle school, vocational high school and the university levels. There were significant decreases in the percentages of the male wage earners in the lowest educational levels. The percentages of illiterates declined by almost 50 percent.

Table 2 gives the mean rhw of male wage earners by education level. The mean rhw declined by 2.41 percent between 1994 and 2002. The rhw deterioration over 1994-2002 affected men in all education groups except the university educated. The table also shows that better educated men earn more than the less educated ones. Men with primary education earned 82 and 75 percent of the average wage in 1994 
and 2002 respectively. University educated men earned 200\% of the average wage both in 1994 and 2002. Further, the differential between the well and poorly educated groups widened from 1994 to 2002.

\section{Estimation Results}

\subsection{The Effect of Education}

The Appendix Table A1 presents the estimates of the Mincerian wage equations where education is introduced as the years of the schooling completed by the individual. This assumes that the return for an additional year of schooling is constant across educational levels. The equality of the coefficient estimates on all covariates including years of schooling across different quantiles are rejected in both 1994 and 2002 at 5 percent level of significance. Test results are available upon request. This suggests that the OLS (mean) returns mask the significant variation in returns across the wage distribution. The OLS and the quantile returns are all positive and statistically significant at one percent level in both 1994 and 2002.

The extended wage equation estimates include dummy variables indicating different levels of education completed by the individual in place of years of schooling. This specification presented in Apppendix Table A2, allows returns to schooling to differ at each level of education.. The coefficient estimates on different levels of education are all positive and statistically significant except those for the nongraduate group in 2002 and some education levels in the first quantile. Differences between educational groups are substantial indicating positive contribution of education to inequality. 
We next examine the return to education at different quantiles. The results of the F-tests confirm that the quantile returns at different points of the wage distribution are significantly different from one another at five percent level of significance in both 1994 and 2002. Thus, the OLS results which provide the return estimates at the mean of the wage distribution mask important differences in the return estimates at different points of the wage distribution indicating that schooling is not uniformly rewarded in the labor market. Thus, education increases within-group wage dispersion. Table 3 provides the q90-q10 and q75-q25 spreads for each of the covariates. We observe that in general, the q90-q10 spread is larger than the q75-q25 spread indicating that wage dispersion takes place mostly at the tails of the wage distribution. In 2002, university education makes the largest contribution to within-group wage inequality.

Martins and Pereira (2004) and Budria and Pereira (2005) in several European countries, Falaris (2004) in Panama, Machado and Mata (2001) and Hartog et al. (2001)in Portugal and Blom et al. (2001) in Brazil find that returns to education at various levels increased across quantiles. Girme and Kedir (2003) find declining returns over the wage distribution at all levels of education in Ethiopia. Mwabu and Schultz (1996) find for Africans, primary school returns decline, secondary school returns have a U-shape and the university returns are homogenous across the quantiles.

Next, we examine the changes in the effects of education over time. Appendix tables show that the median (q50) returns across all education groups decreased from 1994 to 2002 except at the primary level contributing towards wage compression. Table 3 shows that within-groups wage inequality increased since the change in q90q10 spread increased in all education levels over 1994-2002. The former effect may 
have offset or even reversed the latter effect, producing the observed decline in male wage inequality over 1994-2002 The largest increase in the spread was at the university level with 27 percentage points. Providing an explanation for the underlying causes this increased heterogeneity is deferred to future studies. However, one may surmise that changes in the distribution of study subjects and the quality of the university degrees awarded may have contributed to this process. For instance, the recent expansion of the university system meant establishment of universities with inadequate physical facilities and teaching staff. This may have contributed to low quality of qualifications awarded by the recently established universities. Second the expansion of the university system meant an increase in the number of graduates in study subjects such as social sciences, as opposed to technical fields, which are less valued in the labor market. Third, the expansion of the university system may have increased low ability individuals accessing the university education. Differences in ability influences the amount of human capital acquired in school which translates into wage differences in the labor market. Assuming complementarity of ability and education, returns earned by individuals at the lower end of the wage distribution will decrease, increasing the dispersion of wages. There is increased heterogeneity at other education levels also which is harder to explain. The educational reform of 1997 made the middle schooling compulsory and universal which may have increased the heterogeneity in the ability levels of the graduates at this level. Other explanations include educational mismatches in the labor market, differences in school quality and over education. Further research needs to be done on this issue which is deferred to future studies.

Budria and Pereira (2005) found that in Greece, Norway and Italy education contributed towards overall wage dispersion. In Germany, UK; France and Finland the 
impact of education was ambiguous due to opposing between and within-group effects. In Portugal and Sweden, education contributed to a decline in inequality. Patrinos et al. (2009) found that wage effects of education increased within-group inequality in most of the Latin American countries and decreased it in most of the East Asian countries.

\subsection{Per Year Returns to Education}

The OLS estimates and the estimates at different quantiles of the per year returns to education are reported in Table 4. Four salient observations emerge. Non graduates are insignificant, therefore will not be discussed. First, the returns increase over different levels of education so that highest returns are achieved at the university level. This is in contrast to the diminishing returns to schooling hypothesis. There are two possible reasons for the high returns at the university level. One is that the supply of university educated labor restricted by the capacity of the limited number of universities relative to the demand. The other is that, due to the highly competitive national university entrance examination the students selected to enter a university program are high ability individuals. Since our analysis does not control for the ability of the individuals and this selection process, the returns at the university level are high. Second, the returns at different education levels differ across the quantiles of the wage distribution. In 2002, the returns increase across the quantiles at all education levels. Third, there are significant declines in returns between 1994 and 2002 at all levels of education both at the mean of the wage distribution (OLS estimates) and at various quantiles. The declines may be due to the increased relative supply of educated labor and the decreased relative demand for labor due to the adverse labor market effects of the 2001 economic crisis. Fourth, the returns to vocational high school are significantly higher than the returns to high school both at the mean of the 
wage distribution and at all over the entire wage distribution. This is in contrast to the general pattern observed in most of the countries. However, it is in conformity with the previous studies on Turkey (Tansel, 1994; 1996; 2005 and 2008).

\subsection{The Effects of Various Covariates}

The Appendix tables indicate that workers at the lowest tail of the wage distribution obtained the highest wage premium to an additional year of potential labor market experience implying that experience contributed to the decline in wage inequality. The public sector premium declined across the quantiles in both years (expect at the q25 in 2002) indicating that public sector employment and contributes to lower wage inequality. Tansel (2005) also reported wage compression in the public sector in Turkey. Falaris (2004) in Panama, Mueller (1998) in Canada, Nielsen and Rosholm (2001) in Zambia, Machado and Mata (2001) in Portugal found relatively high public sector wage premiums at lower quantiles of the wage distribution. Patrinos et al. (2009) found that education had inequality decreasing effect in the public sector but not in the private sector in East Asian countries. Similarly, urban employment contributed towards lower wage inequality in both years.

In 1994, the effects of working for a medium sized firm (10-25 workers) were insignificant at most of the quantiles and negative when significant. In 2002 the medium sized and large firms (larger than 25) provided positive premiums. There was an increasing trend in 1994 and a decreasing trend in 2002 over the quantiles with opposite implications about the within-groups inequality. Falaris (2004) in Panama and Schaffner (1998) in Peru find declining firm-size effect and Machado and Mata (2001) in Portugal increasing firm size effect across the wage distribution. The estimated models also included industry indicators which are shown in Tables A1, A2 
and A3 for brevity. In 1994 (2002), out of the 14 industries only the seven (four) industry indicators were statistically significant across most of the quantiles. The workers in mining, manufacturing, construction, electric water and gas, hotels and restaurants, transportation and finance sectors have positive and declining returns across the quantiles. They can be interpreted as egalitarian industries (Machado and Mata, 2001).

\section{Digression on Rising Within-Group Wage Inequality}

In this section we discuss the possible causes of rising within-group wage inequality. During the 1980s the wage inequality in the US increased tremendously as a result of the increase in wages of the more skilled workers relative to that of the lessskilled workers (Bound and Johnson, 1992: Katz and Murphy, 1992; Juhn et al., 1992). Economists agree that this is the result of an increase in the relative demand for skilled labor. However there is no agreement over the cause of the relative demand shift for skilled labor. Leamer (1993; 1994), Borjas and Ramey (1995), Feenstra and Hanson (1996) and Wood (1994) and others argued that the resources shifted towards industries that use skilled labor relatively intensively as a result of the increased import competition from low-wage countries. On the other hand, Davis and Haltiwanger (1991), Bound and Johnson (1992), Lawrence and Slaughter (1993), Berman et al. (1994) argued that the recent technological changes caused firms to switch to the production techniques that are biased in favor of skilled labor. Hijzen (2007) found that the skill-biased technological change is the predominant force behind the increase in wage inequality in the UK during the 1990s while outsourcing played a significant role but not to the same extent. Although these issues are extensively studied in the developed countries, they are not often studied in developing countries. However, there is evidence that the wage inequality increased in 
these countries also. Berman et al.(1998) suggest that implications of the skill-biased technological change for income inequality may be greater in developing countries where less-skilled labor is already impoverished. Feenstra and Hanson (1996 and 1997) argue that the capital flows from North to South with outsourcing by Northern multinationals contributed to an increase in the relative demand for skilled labor raising the wage inequality in both the sending and the recipient countries. Hanson and Harrison (1999) and Feliciano (2001) find that trade liberalization which Mexico undertook between 1986 and 1990 disproportionally affected low-skilled industries whose price have fallen and the relative price of skill-intensive industries increased, increasing wage inequality. Hsieh and Woo (2005) study the impact of outsourcing to China on low-skilled workers in Hong Kong. They find that affected the relative demand for skilled workers and their wages were affected in Hong Kong contributing to wage inequality. This review shows that a combination of outsourcing trade and technology change can account for the shift in wages towards skilled labor and increased wage inequality

Turkey adopted a stabilization and structural adjustment program in January, 1980. A major trade liberalization program was initiated. The import substitution policies of the past two decades were replaced by export promoting policies. Measures were taken to encourage FDI. Increased openness to trade and global skillbiased technological chance may have increased the relative wages of skilled labor contributing to the high level of wage inequality in Turkey. FDI inflows were only 0.15 and 0.37 percent of the gross domestic product in 1981 and 1994 respectively. It further increased substantially to 1.68 percent in 2001 (computed using the data provided on the web page of the State Panning Organization). FDI inflows were 2.02 and 12.42 percent of the gross fixed capital formation in 1994 and 2001 respectively 
(Şenses and Koldaş, 2005). The recent increase in the FDI inflows may be a factor behind the rising within-group wage inequality discussed in this paper. These propositions are not investigated but are deferred to future work. Finally, high inequality in Turkey could also be related to the supply of skills. In Turkey not only the cost of higher education is high but also the cost of getting high quality higher education is high. For instance it is difficult and requires investment throughout the school years to go to the universities, the graduates of which are sought after.

\section{Conclusions}

This paper studies the male wage inequality and its evolution from 1994 to 2002 in Turkey using quantile regression techniques. The salient findings can be listed as follows. First, male wage inequality in Turkey is high. Although the male wage inequality exhibited a small decline over the 1994-2002 period a closer examination indicates that wage inequality declined at the bottom end of the wage distribution and increased at the top end of wage distribution. Second, all education levels contributed positively to the wage inequality through both within and between dimensions. Third, the returns to different schooling levels declined significantly from 1994 to 2002. There were two factors responsible for this decline. One is the substantial improvement in the educational attainment of the working population recently and other is the severe economic crisis of 2001 which adversely affected the labor market. These factors suggest that there was a shift in the labor supply while at the same time labor demand remained stable or declined. Fourth, the within-group male wage inequality has increased while the between-group male wage inequality declined over the study period. The latter decline may have offset or reversed the former increase contributing to the observed overall decline in male wage inequality from 1994 to 2002. Fifth, experience, public employment and living in urban areas all contributed 
to lower male wage inequality through the within dimension in both 1994 and 2002.

The largest contribution was by public employment. Working for a large firm contributed to higher male wage inequality in 1994 and lower male wage inequality in 2002. Finally, recent increases in the foreign direct investment inflows, openness to trade and global technological developments favoring skilled labor are discussed as the possible causes of the recent rising within-groups wage inequality.

\section{References:}

Abadie, A. (1997) “Changes in Spanish Labor Income Structure during the 1980’s: A Quantile Regression Approach,” Investigaciones Económicas, 21(2), 253-272. Andini, C. (2007) "Within-Groups Wage Inequality and Schooling: Further Evidence for Portugal,” Bonn, Germany: Institute for the Study of Labor (IZA) Discussion Paper No. 2828.

Berman, E., J. Bound and Z. Griliches (1994) “Changes in the Demand for Skilled Labor within U.S. Manufacturing: Evidence from the Annual Survey of Manufacturers,” Quarterly Journal of Economics, 10: 367-398.

Berman, E. J. Bound and S. Machin (1998) “Implications of Skill-Biased Technological Change: International Evidence,” Quarterly Journal of Economics, 113(4): 1245-79.

Bircan, F. (2005) Three Essays on Education in Turkey. Unpublished Ph. D. thesis, Ankara: Department of Economics, Middle East Technical University.

Blom, A. L., Holm-Nielson and D. Verner (2001) "Education, Earnings, and Inequality in Brazil, 1982-1998: Implications for Education Policy,” Peabody Journal of Education, 76 (3\&4): 180-221.

Borjas, G. J. and V.A. Ramey (1995) “Foreign Competition, Market Power, and Wage Inequality: Theory and Evidence,” Quarterly Journal of Economics, 110: 1075-1111. 
Bound, J. and G. Johnson (1992) "Changes in the Structure of Wages in the 1980s: An Evaluation of Alternative Explanations,” American Economic Review, 82(3): 371-92. Buchinsky, M. (1994) “Changes in the U.S. Wage Structure 1963-1987: Application of Quantile Regression,” Econometrica, (62)2: 405-458.

Buchinski, M. (1998a) “The Dynamics of Changes in the Female Wage Distribution in the USA: A Quantile Regression Approach,” Journal of Econometrics 13: 1-30.

Buchinsky, M. (1998b) “Recent Advances in Quantile Regression Models: A Practical Guideline for Empirical Research,” The Journal of Human Resources, 33(1): 88-126. Budria, S. and P.T. Pereira (2005) "Educational Qualifications and Wage Inequality: Evidence for Europe,” Bonn, Germany: Institute for Study of Labor (IZA) Discussion Paper No. 1763.

Budria, S. and A.I. Moro-Egido (2008) "Education, Educational Mismatch and Wage Inequality: Evidence for Spain,” Economics of Education Review, 27(3): 332-341.

Davis, S.J. and J. Haltiwanger (1991) “Wage Dispersion Between and Within U.S. Manufacturing Plants, 1963-86, Brookings Papers on Economic Activity:

Microeconomics, 1991: 115-200.

Falaris, E. M. (2008) “A Quantile Regression Analysis of Wages in Panama,” Review of Development Economics, 12 (3): 498-514.

Feenstra, R.C, and G. H. Hanson (1996) "Globalization, Outsourcing, and Wage Inequality" American Economic Review Papers and Proceedings, 86(2): 240-

245.

Feenstra, R. C. and G. H. Hanson (1997) “Foreign Direct Investment And Relative Wages: Evidence from Mexico's Maquiladoras,” Journal of International Economics, 42(3/4): 371-393. 
Feliciano, Z. (2001) "Workers and Trade Liberalization: The Impact of Trade

Reforms in Mexico on Wages and Employment,” Industrial and Labor Relations

Review, 55(1): 95-115.

Ferstere, J. and R. Winter-Ebmer (1999) “Are Austrian Returns to Education Falling

Over Time?” Labor Economics, 10: 73-89.

Gernandt, J. and F. Pfeiffer (2006) "Rising Wage Inequality in Germany,” Bonn, Germany: Center for European Economic Research (ZEW) Discussion Paper No: 06019.

Girma, S. and A. Kedir (2003) "Is Education More Beneficial to the Less Able? Econometric Evidence from Ethiopia,” Department of Economics Working Paper No: 03/1. University of Leicester, UK.

Gosling, A. S. Machin, C. Meghir (2000) “The Changing Distribution of Male Wages in the U.K.,” The Review of Economic Studies, 67(4): 635-666.

Hanson, G. and A. Harrison (1999) “Trade Liberalization and Wage Inequality in Mexico,” Industrial and labor Relations Review, 52(2): 271-288.

Hartog, J. P. Pereia and A. C. Vieira (2001) "Changing Returns to Education in Portugal During the 1980s and Early 1990s: OLS and Quantile Regression Estimators,” Applied Economics, 33: 1021-1037.

Hijzen, A. (2007) “International Outsourcing Technological Change and Wage Inequality,” Review of International Economics, 15(1): 188-205.

Hsieh C.T. and K. T. Woo (2005) “The Impact of Outsourcing to China on Hong Kong’s Labor Market,” American Economic Review, 95(5): 1673-1687.

Juhn, C. K. M. Murphy and B. Pierce (1993) "Wage Inequality and the Rise in Returns to Skill,” The Journal of Political Economy, 101(3): 410-442.

Katz, L. and K.M. Murphy (1992) “Changes in Relative Wages, 1963-1987: Supply and Demand Factors,” Quarterly Journal of Economics, 107: 35-78. 
Koenker, R. and K. Hallock (2001) “Quantile Regression,” Journal of Economic Perspectives, 15(4): 143-156.

Koenker, R. G. Basset (1978) “Regression Quantiles,” Econometrica, 46(1): 33-50.

Lawrence, R. Z. and M. J. Slaughter (1993) “Trade and U.S. Wages: Great Sucking

Sound or Small Hiccup? Brookings Papers on Economic Activity, 2: 161-227.

Leamer, E. (1993) Wage Effects of a U.S.-Mexico Free Trade Agreement, in: P.M.

Garber, ed., The Mexico-U.S. Free Trade Agreement, Cambridge, Massachusets:

MIT Press, 57-128.

Leamer, E. (1994) “Trade, Wages, and Revolving Door Ideas,” Cambridge, Massachusets: National Bureau of Economic Research (NBER) Working Paper No: 4716.

Lemieux, T. (2007) “The Changing Nature of Wage Inequality” Cambridge, MA: National Bureau of Economic Research (NBER) Working Paper No: 13523.

Machado, J. F. and J. Mata (2001) "Earning Functions in Portugal 1982-1994:

Evidence from Quantile Regression,” Empirical Economics, 26: 115-134.

Machado, J. F. and J. Mata (2005) Counterfactual Decomposition of Changes in Wage Distributions using Quantile Regression,” Journal of Applied Econometrics, 20(4): $445-465$

Martins, P. S. and P. T. Pereira (2004) “Does Education Reduce Wage Inequality? Quantile Regression Evidence from 16 Countries,” Labor Economics, 11(3): 355-371. Martins, P. (2004) "Industry Wage Dispersion: Evidence from the Wage Distribution,” Economics Letters, 83(2): 157-163.

McGuinness, S., F. McGinnity and P.J. O’Connell (2009) “Changing Returns to Education during a Boom? The Case of Ireland,” Labour, 23: 197-221.

Mincer, J. (1974) Schooling, Experience and Earnings, New York: National Bureau of Economic Research. 
Mueller, R.E. (1998) “Public-Private Sector Wage Differentials in Canada: Evidence from Quantile Regressions,” Economics Letters, 60(2): 229-235.

Mwabu, G. and T. P. Schultz (1996) "Education Returns Across Quantiles of the Wage Function: Alternative Explanations for Returns to Education by Race in South Africa,” The American Economic Review Papers and Proceedings, 86 (2): 335-339.

Nielsen, H.S. and M. Rosholm (2001) “The Public-Private Sector Wage Gap in Zambia in the 1990s: A Quantile Regression Approach,” Empirical Economics, 26: 169-182.

Patrinos, H.A., C. Ridao-Cano and C. Sakellarion (2009) “A Note on Schooling and Wage Inequality in Public and Private Sector,” Empirical Economics, 37: 383-392. Pereira, P. T. and P. S. Martins (2002) “Is there a Return-Risk Link in Education,” Economic Letters, 75: 31-37.

Pereira, P. T. and P. S. Martins (2004) “Does Education Reduce Wage Inequality? Quantile Regressions Evidence from Fifteen European Countries,” Labour Economics, 11(3): 355-371.

Prasad, E. (2000) “The Unbearable Stability of the German Wage Structure: Evidence and Interpretation,” Washington, D.C.: International Monetary Fund Working Paper, 00/02.

Prieto-Rodriguez, C. P. Barros and J. A. C. Vieira (2008) “What a Quantile Approach can Tell Us about Returns to Education in Europe?” Education Economics, 16(4): 391-410.

Schaffner, J. A. (1998) "Premiums to Employment in Larger Establishments: Evidence from Peru,” Journal of Development Economics, 55(1): 81-113. Şenses F. and T. Koldaş (2005) “Some Salient Features of Recent Turkish DFI Experience with Special Emphasis on Export and Employment Performance," METU Studies in Development, Vol. 32(2): 409-431. 
Turkish Statistical Institute (TURKSTAT) (2006) Population and Development Indicators. Population and Education Indicators.

http://www.tuik.gov.tr

Turkish Statistical Institute (TURKSTAT) (2007) Household Budget Survey: Income Distribution 2004. Ankara: Turkish Statistical Institute Publication No: 3087.

Tansel, A. (1994) "Wage Employment, Earnings and Returns to Schooling for Men and Women in Turkey,” Economics of Education Review, 13(4): 305-320.

Tansel, A. (1996) Self Employment, Wage Employment and Returns to Education for Urban Men and Women in Turkey,” in Education and the Labor Market in Turkey ed. by Tuncer Bulutay, SIS Publication, Ankara. pp.175-208. See also Tansel, A. (2001) “Self-Employment, Wage-Employment, and Returns to Schooling by Gender in Turkey”, in Labor and Human Capital in the Middle East: Studies of Markets and Household Behavior, ed. by Djavad Salehi-Isfahani, Ithaca Press, Reading, UK.

Tansel, A. (2005) "Public-Private Employment Choice, Wage Differentials and Gender in Turkey,” Economic Development and Cultural Change, 53(2): 453-477.

Tansel, A. (2008) “Changing Returns to Education for Men and Women in a Developing Country: Turkey, 1994 and 2002,” Paper presented at the ESPE conference, June 18-21,2008, in London, ECOMOD conference, July 2-4,2008 in Berlin, MEEA conference, March 2009 in Nice, France and ICE-TEA conference, September 1-3, 2010 in Girne, Republic of Northern Cyprus.

Wood, A. (1994) North-South Trade, Employment, and Inequality, Oxford: Clarendon Press, Oxford.

\section{End Notes}

${ }^{1}$ This study does not deal with the wage inequality and the quantile regression wage equation estimates for women. Women's labor force participation is very low in Turkey. It was only 31.2 percent in 1994 and declined to 27.9 percent in 2002. In 
contrast the male labor force participation was 78.5 percent in 1994 and declined to 71.6 percent in 2002 (Turkish Statistical Institute, 2006). Therefore, wage equation estimates for women require treatment of non-random selectivity into the labor force. This will be addressed in future research. Several studies in the literature such as Gosling et al. (2000) and Andini (2007) also deal with only male Buchinski (1998a) with only female wage distributions.

${ }^{2}$ The years of schooling is imputed as follows. This variable takes the values of the 0 , 2, 5, 8, 11, 15 and 17 for illiterates, read and write only, primary school, middle school and basic education, high school, university and post university studies graduates respectively 


\begin{tabular}{|c|c|c|c|}
\hline Real Hourly Wage $^{a}$ & 1994 & 2002 & \% Change \\
\hline Mean & 781.25 & 762.47 & -2.41 \\
\hline Standard Deviation & 975.55 & 1094.11 & 12.2 \\
\hline \multicolumn{4}{|l|}{ Quantiles $^{\mathrm{a}}$} \\
\hline q10 & 186.54 & 195.95 & 5.1 \\
\hline q25 & 304.84 & 310.30 & 1.8 \\
\hline q50 & 524.80 & 500.63 & -4.6 \\
\hline q75 & 968.06 & 916.90 & -5.3 \\
\hline q90 & 1548.98 & 1499.02 & -3.3 \\
\hline \multicolumn{4}{|l|}{ Wage Ratios } \\
\hline q90/q10 & 8.30 & 7.65 & -7.8 \\
\hline q90/q75 & 1.60 & 1.64 & 2.5 \\
\hline q90/q50 & 2.95 & 3.00 & 1.7 \\
\hline q50/q10 & 2.81 & 2.56 & -9.0 \\
\hline \multicolumn{4}{|c|}{ Log Wage Dispersion } \\
\hline In q90 - In q75 & 0.47 & 0.49 & 2.0 \\
\hline In q90 - In q50 & 1.08 & 1.097 & 1.7 \\
\hline In q90 - In q10 & 2.12 & 2.03 & -9.0 \\
\hline In q75 - In q50 & 0.61 & 0.61 & 0 \\
\hline In q75 - In q25 & 1.16 & 1.08 & -8.0 \\
\hline In q50 - In q10 & 1.03 & 0.94 & -9.0 \\
\hline In q50 - In q25 & 0.54 & 0.48 & -6.0 \\
\hline \multicolumn{4}{|l|}{$\begin{array}{l}\text { Educational } \\
\text { Distribution (\%) }\end{array}$} \\
\hline Illiterate & 3.99 & 2.05 & -48.6 \\
\hline Non-graduate & 3.10 & 2.65 & -14.5 \\
\hline Primary School & 50.99 & 44.48 & -12.8 \\
\hline Middle School & 12.46 & 14.91 & 19.7 \\
\hline High School & 17.18 & 16.28 & -5.3 \\
\hline Voc. High School & 2.97 & 8.00 & 169.4 \\
\hline University & 9.29 & 11.61 & 25.0 \\
\hline Number of Obs. & 13,181 & 5,847 & \\
\hline
\end{tabular}

Table 1: Summary Measures of Wage Inequality and Educational Distribution for Male Wage-Earners, 1994 and 2002.

Notes: a: The mean hourly real wage and wages at quantiles are in Turkish Lira (TL) base 1987.

Source: Authors' computations using the 1994 Household Income and Expenditure Survey and the 2002 Household Budget Survey. 


\begin{tabular}{lccc}
\hline Level of education & \multicolumn{2}{c}{ Mean Hourly Real Wage } & \% Change \\
& $\mathbf{1 9 9 4}$ & $\mathbf{2 0 0 2}$ & \\
\hline Illiterate & 486.6 & 436.1 & -10.37 \\
& $(4)$ & $(2.2)$ & -24.18 \\
Non-graduate & 575.2 & 436.1 & \\
& $(3.1)$ & $(2.7)$ & -9.56 \\
Primary School & 639.2 & 578.2 & \\
& $(51)$ & $(44.5)$ & -12.11 \\
Middle School & 702.1 & 617.0 & \\
& $(12.5)$ & $(15)$ & -5.11 \\
High School & 895.6 & 849.9 & -17.62 \\
& $(17.2)$ & $(16.3)$ & \\
Vocational High School & 1064.4 & 876.9 & 2.59 \\
& $(3)$ & $(8)$ & \\
University & 1559.9 & 1600.3 & -2.41 \\
Total & $(9.3)$ & $(11.6)$ & \\
& 781 & 762.5 & $(100)$ \\
\hline
\end{tabular}

Table 2: Mean Real Hourly Wages of Male Wage Earners in TL by Education Level, 1994 and 2002.

Notes: The mean hourly real wages are in Turkish Liras (TL) base 1987. The numbers in parentheses are the percent of observations in each category.

Source: Authors' computation using 1994 Household Income and Expenditure Survey and 2002 Household Budget Survey. 


\begin{tabular}{lccccc}
\hline & \multicolumn{2}{c}{1994} & \multicolumn{2}{c}{2002} & Change \\
& q75-q25 & q90-q10 & q75-q25 & q90-q10 & $\Delta$ (q90-q10) \\
\hline Years of Sch. & 0.6 & 0.3 & 1.8 & 2.2 & 2.1 \\
Experience & -0.7 & -1.8 & 0.1 & -1.2 & 0.6 \\
Cohort 25-44 & -0.4 & -1.9 & 1.2 & 2.9 & 0.6 \\
Cohort 45-65 & -2.1 & $\mathrm{a}$ & $\mathrm{a}$ & $\mathrm{a}$ & $\mathrm{a}$ \\
Public Emp. & -10.7 & -32.8 & -19.1 & -31.4 & 1.4 \\
Urban & -4.6 & -8.3 & $\mathrm{a}$ & $\mathrm{a}$ & $\mathrm{a}$ \\
Firm Size 10-25 & $\mathrm{a}$ & $\mathrm{a}$ & -3.9 & 3.1 & $\mathrm{a}$ \\
Firm Size $>$ 25 & 0.1 & $\mathrm{a}$ & -4.0 & -5.5 & $\mathrm{a}$ \\
Education Levels & & & & & \\
Non-Graduate & 2.8 & $\mathrm{a}$ & $\mathrm{a}$ & $\mathrm{a}$ & $\mathrm{a}$ \\
Primary & 3.8 & 10.8 & 1.9 & 18.9 & 8.1 \\
Middle & 5.7 & 7.1 & 6.5 & 22.9 & 15.8 \\
High & 7.3 & 5.4 & 10.9 & 25.2 & 19.8 \\
Voc. High & 10.3 & 6.8 & 13.5 & 30.5 & 23.7 \\
University & 14.6 & 22.5 & 17.1 & 49.6 & 27.1 \\
\hline
\end{tabular}

Table 3: Impact of the Covariates on Measures of Dispersion, 1994 and 2002.

Notes : The differentials are multiplied by 100.

a: These cells are not computed due to insignificance of the relevant coefficient estimates.

Source: Authors' computations using the estimates in Appendix Tables A1-A2. 


\begin{tabular}{|c|c|c|c|c|c|c|}
\hline 1994 & OLS & q10 & $\mathbf{q 2 5}$ & q50 & $\mathbf{q 7 5}$ & $\mathbf{q 9 0}$ \\
\hline Non-graduate & 6.8 & $5.8^{\mathrm{a}}$ & 5.9 & 5.9 & 7.3 & 12.4 \\
\hline Primary School & $4.4^{\mathrm{a}}$ & $3.9^{\mathrm{a}}$ & $4.3^{\mathrm{a}}$ & $3.6^{\mathrm{a}}$ & $5.1^{\mathrm{a}}$ & $6.1^{\mathrm{a}}$ \\
\hline Middle School & 4.1 & 4.6 & 3 & 3.4 & 3.6 & 3.4 \\
\hline High School & 8.5 & 8.6 & 7.4 & 7.5 & 8 & 8 \\
\hline Vocational H. School $^{\mathrm{b}}$ & 13.3 & 13.8 & 12.4 & 13.7 & 13.9 & 13.7 \\
\hline University over High Sch. & 14 & 12.4 & 13.2 & 14 & 15 & 16.6 \\
\hline University over Voc.High Sch. & 10.4 & 8.5 & 9.5 & 9.4 & 10.6 & 12.4 \\
\hline \multicolumn{7}{|l|}{2002} \\
\hline Non-graduate & $-1^{\mathrm{a}}$ & $-0.1^{\mathrm{a}}$ & $0.3^{\mathrm{a}}$ & $1.6^{\mathrm{a}}$ & $1.7^{\mathrm{a}}$ & $0.9^{\mathrm{a}}$ \\
\hline Primary School & 3.6 & $3.1^{\mathrm{a}}$ & 3.8 & 3.7 & 4.2 & 6.8 \\
\hline Middle School & 3.2 & $3.2^{\mathrm{a}}$ & 2.8 & 2.5 & 4.3 & 4.5 \\
\hline High School & 7.1 & 6.9 & 5.4 & 5.9 & 6.9 & 7.7 \\
\hline Vocational H. School $^{\mathrm{b}}$ & 9.8 & 8.3 & 7.9 & 9.6 & 10.2 & 10.9 \\
\hline University over High Sch. & 13.1 & 9.9 & 11.6 & 12.9 & 13.2 & 16 \\
\hline University over Voc.High Sch. & 11.1 & 8.8 & 9.8 & 10.1 & 10.7 & 13.6 \\
\hline
\end{tabular}

Table 4: Per Year Returns to Schooling by School Level, 1994 and 2002.

Notes: a: indicates insignificance.

b: Assuming three years of vocational high school.

Source: Authors' calculations using the estimates in Appendix Table A2. 
Appendix Tables

\begin{tabular}{|c|c|c|c|c|c|c|}
\hline 1994 & OLS & q10 & q25 & q50 & q75 & q90 \\
\hline Years of Sch. & $\begin{array}{c}0.077 \\
(34.68) * * *\end{array}$ & $\begin{array}{c}0.078 \\
(21.82)^{* * *}\end{array}$ & $\begin{array}{c}0.069 \\
(33.69)^{* * *}\end{array}$ & $\begin{array}{c}0.07 \\
(29.01)^{* * *}\end{array}$ & $\begin{array}{c}0.075 \\
(27.50)^{* * *}\end{array}$ & $\begin{array}{c}0.081 \\
(15.53)^{* * *}\end{array}$ \\
\hline Experience & $\begin{array}{c}0.062 \\
(25.15)^{* * *}\end{array}$ & $\begin{array}{c}0.075 \\
(26.04)^{* * *}\end{array}$ & $\begin{array}{c}0.061 \\
(25.09)^{* * *}\end{array}$ & $\begin{array}{c}0.056 \\
(19.40)^{* * *}\end{array}$ & $\begin{array}{c}0.054 \\
(20.28)^{* * *}\end{array}$ & $\begin{array}{c}0.057 \\
(9.01)^{* * *}\end{array}$ \\
\hline Experience Sq. & $\begin{array}{c}-0.001 \\
(20.40)^{* * *}\end{array}$ & $\begin{array}{c}-0.001 \\
(19.14)^{* * *}\end{array}$ & $\begin{array}{c}-0.001 \\
(20.37)^{* * *}\end{array}$ & $\begin{array}{c}-0.001 \\
(12.83)^{* * *}\end{array}$ & $\begin{array}{c}-0.001 \\
(15.43)^{* * *}\end{array}$ & $\begin{array}{c}-0.001 \\
(6.41)^{* * *}\end{array}$ \\
\hline Cohort 25-44 & $\begin{array}{c}0.196 \\
(8.41)^{* * *}\end{array}$ & $\begin{array}{c}0.195 \\
(5.60)^{* * *}\end{array}$ & $\begin{array}{c}0.199 \\
(7.15)^{* * *}\end{array}$ & $\begin{array}{c}0.182 \\
(6.82)^{* * *}\end{array}$ & $\begin{array}{c}0.195 \\
(7.34)^{* * *}\end{array}$ & $\begin{array}{c}0.176 \\
(3.30)^{* * *}\end{array}$ \\
\hline Cohort 45-65 & $\begin{array}{c}0.097 \\
(2.52)^{* *}\end{array}$ & $\begin{array}{c}0.118 \\
(1.88)^{*}\end{array}$ & $\begin{array}{c}0.133 \\
(2.86)^{* * *}\end{array}$ & $\begin{array}{c}0.104 \\
(2.18)^{* *}\end{array}$ & $\begin{array}{c}0.154 \\
(3.43)^{* * *}\end{array}$ & $\begin{array}{c}0.1 \\
(-1.27)\end{array}$ \\
\hline Public Emp. & $\begin{array}{c}0.473 \\
(26.70)^{* * *}\end{array}$ & $\begin{array}{c}0.604 \\
(22.88)^{* * *}\end{array}$ & $\begin{array}{c}0.586 \\
(25.18)^{* * *}\end{array}$ & $\begin{array}{c}0.576 \\
(29.95)^{* * *}\end{array}$ & $\begin{array}{c}0.479 \\
(22.55)^{* * *}\end{array}$ & $\begin{array}{c}0.276 \\
(9.44)^{* * *}\end{array}$ \\
\hline Urban & $\begin{array}{c}0.173 \\
(11.37)^{* * *}\end{array}$ & $\begin{array}{c}0.184 \\
(9.30)^{* * *}\end{array}$ & $\begin{array}{c}0.193 \\
(13.01)^{* * *}\end{array}$ & $\begin{array}{c}0.178 \\
(10.26)^{* * *}\end{array}$ & $\begin{array}{c}0.147 \\
(9.80)^{* * *}\end{array}$ & $\begin{array}{c}0.101 \\
(4.79)^{* * *}\end{array}$ \\
\hline Firm Size 10-25 & $\begin{array}{l}-0.027 \\
(-1.19)\end{array}$ & $\begin{array}{c}0.02 \\
(-0.7)\end{array}$ & $\begin{array}{l}-0.025 \\
(-1.05)\end{array}$ & $\begin{array}{c}-0.069 \\
(2.93)^{* * *}\end{array}$ & $\begin{array}{c}-0.07 \\
(2.99)^{* * *}\end{array}$ & $\begin{array}{l}-0.043 \\
(-0.94)\end{array}$ \\
\hline Firm Size > 25 & $\begin{array}{c}0.063 \\
(3.84)^{* * *}\end{array}$ & $\begin{array}{l}0.035 \\
-1.55\end{array}$ & $\begin{array}{c}0.061 \\
(2.82)^{* * *}\end{array}$ & $\begin{array}{c}0.08 \\
(4.48)^{* * *}\end{array}$ & $\begin{array}{c}0.062 \\
(2.91)^{* * *}\end{array}$ & $\begin{array}{c}0.081 \\
(2.60)^{* * *}\end{array}$ \\
\hline Constant & $\begin{array}{c}4.728 \\
(95.70)^{* * *}\end{array}$ & $\begin{array}{c}3.754 \\
(39.57)^{* * *}\end{array}$ & $\begin{array}{c}4.345 \\
(81.24)^{* * *}\end{array}$ & $\begin{array}{c}4.826 \\
(90.18)^{* * *}\end{array}$ & $\begin{array}{c}5.192 \\
(90.73)^{* * *}\end{array}$ & $\begin{array}{c}5.632 \\
(41.93)^{* * *}\end{array}$ \\
\hline Observations & 13,181 & 13,181 & 13,181 & 13,181 & 13,181 & 13,181 \\
\hline 2002 & OLS & q10 & q25 & q50 & q75 & q90 \\
\hline Years of Sch. & $\begin{array}{c}0.076 \\
(23.94)^{* * *}\end{array}$ & $\begin{array}{c}0.067 \\
(13.60)^{* * *}\end{array}$ & $\begin{array}{c}0.062 \\
(16.32)^{* * *}\end{array}$ & $\begin{array}{c}0.07 \\
(24.55)^{* * *}\end{array}$ & $\begin{array}{c}0.08 \\
(17.54)^{* * *}\end{array}$ & $\begin{array}{c}0.091 \\
(13.54)^{* * *}\end{array}$ \\
\hline Experience & $\begin{array}{c}0.044 \\
(11.99)^{* * *}\end{array}$ & $\begin{array}{c}0.057 \\
(7.70)^{* * *}\end{array}$ & $\begin{array}{c}0.044 \\
(9.40)^{* * *}\end{array}$ & $\begin{array}{c}0.042 \\
(9.13)^{* * *}\end{array}$ & $\begin{array}{c}0.045 \\
(8.10)^{* * *}\end{array}$ & $\begin{array}{c}0.045 \\
(5.47)^{* * *}\end{array}$ \\
\hline Experience Sq. & $\begin{array}{c}-0.001 \\
(8.54)^{* * *}\end{array}$ & $\begin{array}{c}-0.001 \\
(6.57)^{* * *}\end{array}$ & $\begin{array}{c}-0.001 \\
(7.79)^{* * *}\end{array}$ & $\begin{array}{c}-0.001 \\
(6.97) * * *\end{array}$ & $\begin{array}{c}-0.001 \\
(5.64)^{* * *}\end{array}$ & $\begin{array}{c}0 \\
(2.93)^{* * *}\end{array}$ \\
\hline Cohort 25-44 & $\begin{array}{c}0.165 \\
(4.83)^{* * *}\end{array}$ & $\begin{array}{c}0.158 \\
(2.81)^{* * *}\end{array}$ & $\begin{array}{c}0.14 \\
(4.29)^{* * *}\end{array}$ & $\begin{array}{c}0.16 \\
(4.82)^{* * *}\end{array}$ & $\begin{array}{c}0.152 \\
(3.59)^{* * *}\end{array}$ & $\begin{array}{c}0.129 \\
(2.01)^{* *}\end{array}$ \\
\hline Cohort 45-65 & $\begin{array}{c}0.104 \\
(1.91)^{*}\end{array}$ & $\begin{array}{c}0.136 \\
(1.83)^{*}\end{array}$ & $\begin{array}{c}0.136 \\
(2.62)^{* * *}\end{array}$ & $\begin{array}{c}0.11 \\
(2.05)^{* *}\end{array}$ & $\begin{array}{l}0.097 \\
-1.62\end{array}$ & $\begin{array}{l}0.006 \\
-0.06\end{array}$ \\
\hline Public Emp. & $\begin{array}{c}0.473 \\
(14.57)^{* * *}\end{array}$ & $\begin{array}{c}0.583 \\
(13.11)^{* * *}\end{array}$ & $\begin{array}{c}0.624 \\
(19.77)^{* * *}\end{array}$ & $\begin{array}{c}0.534 \\
(15.08)^{* * *}\end{array}$ & $\begin{array}{c}0.433 \\
(10.32)^{* * *}\end{array}$ & $\begin{array}{c}0.267 \\
(4.40)^{* * *}\end{array}$ \\
\hline Urban & $\begin{array}{c}0.097 \\
(3.45)^{* * *}\end{array}$ & $\begin{array}{c}0.184 \\
(3.83)^{* * *}\end{array}$ & $\begin{array}{c}0.187 \\
(6.05)^{* * *}\end{array}$ & $\begin{array}{c}0.139 \\
(4.48)^{* * *}\end{array}$ & $\begin{array}{l}0.045 \\
-1.05\end{array}$ & $\begin{array}{c}-0.044 \\
-0.81\end{array}$ \\
\hline Firm Size 10-25 & $\begin{array}{c}0.168 \\
(7.23)^{* * *}\end{array}$ & $\begin{array}{c}0.141 \\
(3.81)^{* * *}\end{array}$ & $\begin{array}{c}0.156 \\
(5.52)^{* * *}\end{array}$ & $\begin{array}{c}0.125 \\
(4.81)^{* * *}\end{array}$ & $\begin{array}{c}0.117 \\
(5.01)^{* * *}\end{array}$ & $\begin{array}{c}0.172 \\
(3.53)^{* * *}\end{array}$ \\
\hline Firm Size > 25 & $\begin{array}{c}0.297 \\
(13.54)^{* * *}\end{array}$ & $\begin{array}{c}0.333 \\
(12.04)^{* * *}\end{array}$ & $\begin{array}{c}0.313 \\
(13.55)^{* * *}\end{array}$ & $\begin{array}{c}0.262 \\
(10.28)^{* * *}\end{array}$ & $\begin{array}{c}0.273 \\
(10.92)^{* * *}\end{array}$ & $\begin{array}{c}0.278 \\
(7.79)^{* * *}\end{array}$ \\
\hline Constant & $\begin{array}{c}4.551 \\
(59.13)^{* * *}\end{array}$ & $\begin{array}{c}3.413 \\
(24.18)^{* * *}\end{array}$ & $\begin{array}{c}4.199 \\
(46.40)^{* * *}\end{array}$ & $\begin{array}{c}4.656 \\
(39.59)^{* * *}\end{array}$ & $\begin{array}{c}5.073 \\
(49.15)^{* * * *}\end{array}$ & $\begin{array}{c}5.477 \\
(31.95)^{* * * *}\end{array}$ \\
\hline Observations & 5,847 & 5,847 & 5,847 & 5,847 & 5,847 & 5,847 \\
\hline
\end{tabular}

Table A1: OLS and Quantile Regression Estimates of the Wage Equations, 1994 \& 2002.

Notes : The estimated equations also include industry indicators which are not shown for brevity.

Source: Authors' estimates using 1994 Household Income and Expenditure Survey and 2002 Household Budget Survey. 


\begin{tabular}{lcccccc}
\hline 1994 & OLS & $\mathbf{q 1 0}$ & $\mathbf{q 2 5}$ & $\mathbf{q 5 0}$ & $\mathbf{q 7 5}$ & $\mathbf{q 9 0}$ \\
\hline Non-grad. & 0.136 & 0.115 & 0.118 & 0.117 & 0.146 & 0.248 \\
& $(3.24)^{* * *}$ & -0.94 & $(1.99)^{* *}$ & $(2.27)^{* *}$ & $(2.82)^{* * *}$ & $(3.00)^{* * *}$ \\
Primary Sch. & 0.219 & 0.194 & 0.217 & 0.18 & 0.255 & 0.302 \\
& $(6.81)^{* * *}$ & $(2.07)^{* *}$ & $(4.74)^{* * *}$ & $(4.97)^{* * *}$ & $(6.52)^{* * *}$ & $(4.06)^{* * *}$ \\
Middle Sch. & 0.343 & 0.332 & 0.306 & 0.281 & 0.363 & 0.403 \\
& $(9.42)^{* * *}$ & $(3.69)^{* * *}$ & $(6.39)^{* * *}$ & $(6.20)^{* * *}$ & $(6.56)^{* * *}$ & $(4.51)^{* * *}$ \\
High Sch. & 0.598 & 0.589 & 0.529 & 0.506 & 0.602 & 0.643 \\
& $(16.06)^{* * *}$ & $(6.07)^{* * *}$ & $(10.17)^{* * *}$ & $(9.98)^{* * *}$ & $(11.40)^{* * *}$ & $(7.53)^{* * *}$ \\
Vocational & 0.741 & 0.746 & 0.677 & 0.691 & 0.78 & 0.814 \\
& $(15.70)^{* * *}$ & $(8.23)^{* * *}$ & $(13.05)^{* * *}$ & $(13.59)^{* * *}$ & $(11.36)^{* * *}$ & $(8.47)^{* * *}$ \\
University & 1.157 & 1.084 & 1.057 & 1.067 & 1.203 & 1.308 \\
& $(27.27)^{* * *}$ & $(11.58)^{* * *}$ & $(26.33)^{* * *}$ & $(23.05)^{* * *}$ & $(31.95)^{* * *}$ & $(21.73)^{* * *}$ \\
\hline & \multicolumn{7}{c}{} & & & & \\
\hline 2002 & \multicolumn{7}{c}{} & & & & \\
\hline Non-grad. & -0.019 & -0.002 & 0.006 & 0.031 & -0.034 & -0.017 \\
& $(-0.25)$ & $(-0.01)$ & $(-0.07)$ & $(-0.49)$ & $(-0.38)$ & $(-0.06)$ \\
Primary Sch. & 0.18 & 0.153 & 0.189 & 0.185 & 0.208 & 0.342 \\
Middle Sch. & $(2.95)^{* * *}$ & $(-0.91)$ & $(2.29)^{* *}$ & $(3.58)^{* * *}$ & $(3.08)^{* * *}$ & $(1.68)^{*}$ \\
& 0.277 & 0.248 & 0.273 & 0.259 & 0.338 & 0.477 \\
High Sch. & $(4.23)^{* * *}$ & $(-1.45)$ & $(3.17)^{* * *}$ & $(4.60)^{* * *}$ & $(4.08)^{* * *}$ & $(2.28)^{* *}$ \\
& 0.491 & 0.456 & 0.436 & 0.436 & 0.545 & 0.708 \\
Vocational & $(7.36)^{* * *}$ & $(2.73)^{* * *}$ & $(5.13)^{* * *}$ & $(7.41)^{* * *}$ & $(6.34)^{* * *}$ & $(3.13)^{* * *}$ \\
& 0.572 & 0.498 & 0.509 & 0.548 & 0.644 & 0.803 \\
University & $(8.15)^{* * *}$ & $(2.89)^{* * *}$ & $(5.82)^{* * *}$ & $(8.87)^{* * *}$ & $(7.56)^{* * *}$ & $(3.48)^{* * *}$ \\
& 1.014 & 0.85 & 0.9 & 0.952 & 1.071 & 1.346 \\
t statistics are in parentheses. *significant at $10 \%)^{* * *}$ significant at $5 \% * * * *$ significant at $1 \%$.
\end{tabular}

Table A2: OLS and the Quantile Regression Estimates of the Wage Equations with Educational Categories, 1994 and 2002

Notes: The variables in the estimated equations include all of the Variables (except years of schooling) shown in the Tables A1 and A2. The coefficient estimates other than schooling are similar to the ones reported in the Tables A1 and A2. For brevity they are not reported here. Further, industry indicators which are included in both years are also not reported for brevity. Source: Authors' estimates based on 1994 Household Income and Expenditure Survey and 2002 Household Budget Survey. 